\title{
A bibliometric analysis on the use of the multicriteria approach to the water resource management
}

\section{Uma análise bibliométrica sobre o uso da abordagem multicritério na gestão dos recursos hídricos}

\author{
Alexandre Troian ${ }^{1}$ [C, Mário Conill Gomes ${ }^{2}$ (1) \\ ${ }^{1}$ Universidade Federal de Pelotas - UFPel, Faculdade de Agronomia Eliseu Maciel, Pelotas, RS, Brasil. \\ E-mail: xtroian@gmail.com \\ ${ }^{2}$ Universidade Federal de Pelotas - UFPel, Faculdade de Agronomia Eliseu Maciel, Pelotas, RS, Brasil. \\ E-mail: mconill@gmail.com
}

How to cite: Troian, A., \& Gomes, M. C. (2020). A bibliometric analysis on the use of the multicriteria approach to the water resource management. Gestão \& Produção, 27(2), e4761.

https://doi.org/10.1590/0104-530X4761-20

\begin{abstract}
The purpose of this article was to accomplish a literature review to analyze the scientific studies which were based on Multicriteria Methods to study water resources management in agriculture. Scientific production indicators were established for the subject, through a descriptive analysis of 519 publications data set generated by the Scopus database search engine. The publications were refined applying several criteria resulting in 30 articles considered to be the most important to interpret the factors that detail the researched topic. The analyzed scientific studies also show that the structuring of multicriteria models is designed to better understand the problem or the process of decision making rather than to make the decisions itself. Furthermore, to the water resources management field, they provide a way to discuss and deal with problems like water distribution and pollution. An aggregating function along with a compensatory approach is used in most publications. Although participatory techniques were not the approach used by most studies, its potential was recognized for dealing with problems such as water management resources.
\end{abstract}

Keywords: Water resource management; Decision-making; Agriculture.

Resumo: $O$ objetivo deste artigo foi o de realizar uma revisão bibliográfica para analisar as produções científicas que fizeram uso de ferramentas multicriteriais para o gerenciamento da água na agricultura. A metodologia utilizada segue um conjunto de processos específicos da pesquisa bibliométrica. Foram estabelecidos indicadores de produção científica, através de análise descritiva dos dados, a partir de 519 publicações geradas pela estrutura de busca na plataforma Scopus. As publicações foram refinadas com a aplicação de critérios de seleção, resultando em 30 artigos que mais adequadamente abordam a temática pesquisada. A produção científica discute à gestão dos recursos hídricos e formas de prevenir e reduzir a poluição da água, a partir da estruturação de modelos multicritérios projetados para entender o problema e o processo da decisão. Nos trabalhos analisados predomina a abordagem compensatória agregando os critérios em uma função de síntese. As abordagens participativas para construção dos modelos não são a maioria, mas identificou-se bom potencial de uso para problemas relacionados à gestão de recursos hídricos.

Palavras-chave: Gestão de recursos hídricos; Tomada de decisão; Agricultura.

Received Apr. 6, 2018 - Accepted Sep. 14, 2018

Financial support: None.

(i) This is an Open Access article distributed under the terms of the Creative Commons Attribution License, which permits unrestricted use, distribution, and reproduction in any medium, provided the original work is properly cited. 


\section{Introduction}

The consequences of the productivity-based development model can be seen in economic, environmental, and even social dimensions. In nature, among several other negative implications to natural ecosystems, these consequences can reflect on a poor commitment with water quality. Following this line of thinking, the main questions in this study will be focused on water resources management.

Although it had been addressed by several constitutions since the Empire period, the water was only discussed objectively in terms of domain (Union, States and Counties) and classification (common public waters and private waters) by the Decree 24,643 of 1934. Later, in the Constitution of 1988 (Brasil, 1988), articles of procedural, penal, economic, sanitary, custodial and administrative nature were established. Since then, water has become public domain and its management is shared among the Union, States and Counties, while the Union remains the only legislative instance (Pes, 2005).

At this time, Brazilian waters are regulated by Law 9,433 of 1997, also known as The Water Law (Lei das águas). It instituted the National Water Resources Policy (NWRP) and the creation of the Catchment Basin Committees (CBC). The committees are institutional arrangements represented by the public power, civil society and water users, responsible for the decentralized and participative management of the water resources (ANA, 2012).

Both the creation of Catchment Basin Committees in Brazil and the growth in the number of diagnoses that involve water sources management are efforts that have shown concern for this natural resource. Nonetheless, water is an element of nature that expresses biologic and socioeconomic value, while its management is complex and involves a multitude of actors with multiple objectives. Through this perspective, even considering that the water resources are not divided by sector, such as agriculture, industry and services, this study will attempt to highlight a methodology that might be able to contribute to the water resources management within agricultural production systems.

The intended objective is to gather bibliometric data that may allow filtering for the scientific studies that approach water resources management with an agricultural view, especially those in which a Multicriteria Method is the main investigation tool. Specifically, the aim is to understand the relevance of using this methodology to tackle the problem at hand by identifying what was researched as well as the recent trends. Another goal is creating a database with relevant publications that allow for refinement of the methodology to be used in water management problems. For that purpose, relevant scientific publications from the Scopus database were examined, analyzed and selected based on their relevance to this study.

\section{Theoretical background}

Understanding the elements associated with the farmer's decision making process can be essential to interpret their behavior and stance on adopting conservation practices and techniques. According to Prokopy et al. (2008), structural variables have a greater influence on decisions than personal ones. In this context, this means property size, income, type of agricultural activity and government program participation weigh more than being conscious of environmental problems.

Since farmers differ in structural, cultural and psychological characteristics, this heterogeneity reflects on their spatial and temporal decision making patterns 
(Xavier et al, 2012). The set of decisions made is not defined only by economic rationality. Other factors, such as common sense, accumulated empiric knowledge and family wellbeing are essential to their choices (Lima et al, 2005).

Some studies have been examining the relation between the adoption of conservation practices and the discrete variables of the farmer, like age, education, land tenure and land size. While some emphasize the attitudes and motivations (Lynne et al., 1988; Ryan et al., 2003), others stress different social, economic and structural variables (Tosakana et al., 2010; Napier et al., 2000; Lemke et al., 2010). Despite this, it is highly unlikely that there is a single variable that can, universally, influence the propagation and adoption of conservation practices.

An alternative way to address the multidimensional and subjective aspects associated with the decision making processes in catchment basin management is found through the use of Multicriteria Methodologies. These methods consider the multidimensional and complex nature of the problems while looking for a way to see the weight of each of them in decision making, evaluation or monitoring situations. Whether the objective is to order or categorize, it is intended to allow the involved parties the possibility of choosing the best course of action in each context (Bana e Costa \& Pirlot, 1997).

On international literature, several terminologies can be found on the field of Multicriteria Method, each of them representing a school of thought. A comprehensive analysis of these schools is not within the scope of this study. However, the works of Greco et al. (2016); Ehrgott et al. (2010) and Zopounidis \& Doumpos (2016) constitute a good starting point to understand the relation between these methods and Decision Science.

A small disambiguation effort can be made over this topic, regarding MultiCriteria Decision Analysis and MultiCriteria Decision Aid. In the field of MultiCriteria Analysis (MCA), both of these schools use the same acronym: MCDA. The differences rely on the paradigm through which the basic postulates of the preference theory are interpreted.

The MultiCriteria Decision Analysis is born and consolidated within the scientific community in the 1960s and is found between two major fields of knowledge. The decision and the decision making process are common themes addressed by Administrative Science, whereas Multicriteria Methods are typical of Operational Research (Roy, 1993). Conversely, despite the ELECTRE methods surfacing in the 1960 s and being a key development within the MultiCriteria Decision Aid school, it was only consolidated throughout the 1970s with the organization of the first conference of the European Working Group 'Multicriteria Aid for Decisions' in Brussels, 1975 (Roy \& Vanderpooten, 1996).

Operationally, the Multicriteria Methods for analysis or aid are ways to model complex situations, considering both qualitative (environmental, social, organizational) and quantitative factors (costs involved, physical variables). They provide a psychological foundation that takes several variables into account, such as the behavior of the decision makers in risk situations, imprecision or even lack of understanding (Ensslin et al., 2001).

This seems to be the scenario of the problems related to natural resources usage, especially in the case of water resources. Environmental problems are on a worldwide scale, with many parties involved, long term impact and little detail of possible consequences. Consequently, the environmental problems require political and ethical alternatives based on scientific predictions and techniques of quantitative and 
qualitative nature (Funtowicz \& Ravetz, 1997). This validates an interest on Multicriteria Methods.

In this study, the main objective was to find works about water resources management within the scope of international literature, considering how different authors use methodology and the contribution of each criteria (aggregative or non-aggregative); how they solved the conflict between criteria (compensatory or non-compensatory) and, lastly, how they consider the preferences of the stakeholders in the elaboration of the model (participatory or non-participatory construction). The following section will detail the procedures of data gathering and analysis of the literature.

\section{Methodology}

The set of systemic activities contained in this study is of exploratory nature and aims to find key elements to structure the research problems regarding water resource management. Methodological procedures include knowledge, organization and classification of the publications in which the Multicriteria Method has a key role as a research tool.

A bibliometric analysis was carried out using tools to create indices that descriptively portray the scientific productions about a central problem. Bibliometrics is a branch of Information Science that seeks to measure written communication processes and produce document information surveys (Treinta et al, 2014). Allan Pritchard, in his article Statistical Bibliography or Bibliometrics, from 1969, defines bibliometrics as "[...] the application of mathematics and statistical methods to books and other media of communication [...]" (Pritchard, 1969, p. 349).

Thus, bibliometrics make it possible to build a map of the knowledge structure of a particular scientific field (Vanti, 2002); or, even, a statistical analysis of the scientific publishings for a certain field. Based in the bibliometric method, the procedures used can be split in four steps, illustrated in the Figure 1 below.

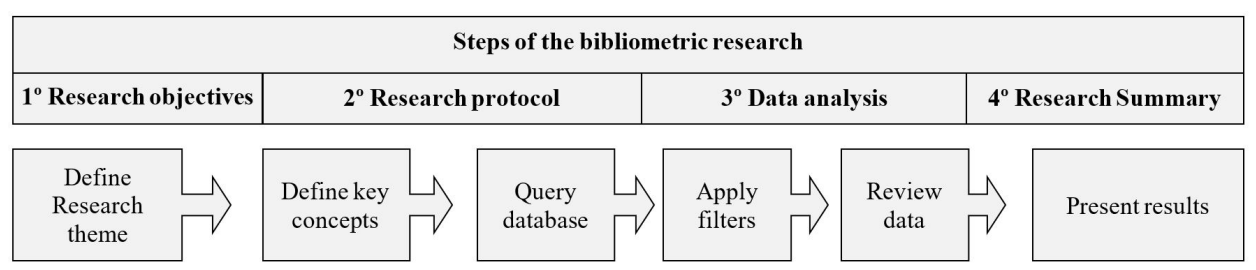

Figure 1. Orienteering Steps for the bibliometric research. Source: Authors.

The first step (research objective) is the establishment of the theme to be studied, in this case: water resources management. As the study progressed, it was possible to refine the problem at hand. The adjustments led to a more specific problem: multicriteria tools for water resources management.

The second step, named research protocol, covers the choice of database, the definition of basic concepts, the search execution and the organization of the document portfolio. Scopus was chosen as it is considered to be the biggest multidisciplinary peer-reviewed literature database: scientific journals, books and conference documents (Elsevier, 2017). In addition, Scopus provides several research and analysis tools that allow for a series of filters to fine tune the publications shown (by timeframe, type of publication, language, area of interest, and others). 
Still in this stage, basic concepts to be explored as well as the search query for the database are defined. Firstly, a couple of simple and compound words considered relevant to the topic were appointed and organized in four different categories. Following this, eight search queries were constructed for the initial tests on the Scopus platform. After testing, the need to eliminate similar words was verified, resulting in the reduction of categories from four to three (Chart 1 ).

Chart 1. Key words and search structure used in bibliometric research.

\begin{tabular}{|c|c|c|}
\hline Axis 1 - Key words & Axis 2 - Key words & Axis 3 - Key words \\
\hline $\begin{array}{l}\text { Environmental management; } \\
\text { Water resource; Water } \\
\text { management; Water } \\
\text { conservation; watersheds; } \\
\text { Catchment }\end{array}$ & $\begin{array}{l}\text { Farmer; Agriculture; Rural } \\
\text { stakeholders; Landowners; } \\
\text { Conservation }\end{array}$ & $\begin{array}{l}\text { Multicriteria; MCDA; } \\
\text { Multi-criteria; Multicriteria } \\
\text { Decision }\end{array}$ \\
\hline \multicolumn{3}{|l|}{ Search query } \\
\hline \multicolumn{3}{|c|}{$\begin{array}{l}\text { "Environmental management" OR "Water resources" OR "Water management" OR "Wate } \\
\text { conservation" OR "watersheds" OR "Catchment" } \\
\text { AND } \\
\text { "Multicriteria Decision" OR " MCDA" OR "Multi-criteria" OR "Multicriteria" } \\
\text { AND } \\
\text { "Farmer" OR "Agricultur" OR "Rural stakeholders" OR "landowners" OR "Conservation" }\end{array}$} \\
\hline
\end{tabular}

Note: the logical OR operator adds words and, with it, the search query identifies publishings with two or more words or documents containing at least one of them. The AND operator was applied to determine publishings with one or more sets of words before it, and with one or more sets after it. A wildcard $\left(^{*}\right)$ was applied to replace any amount of letters. For example: a wildcard in Agricultur* will find documents with the words Agricultural as well as Agriculture.

The assembly of a database began on the third step. Afterwards, filters were applied to keep only the relevant studies. The filters used were the following: (a) Time frame (studies within the time frame of 2000 to 2017); (b) Type of publication (select only peer-reviewed scientific articles for the database); (c) Area of knowledge (limits to only areas of knowledge relevant to the present study); (d) Keywords (defines the words related to the intended search).

A qualitative filter was also applied in this step, through the analysis of titles and abstracts of publications in order to select articles aligned with the study's subject matter. The chosen articles for the sample shown in Chart 2 meet with the following criteria: research problem approach (aggregative or non-aggregative), problem solving techniques (compensatory or non-compensatory), as well as the participation or lack thereof of stakeholders in the model structuring. The information was organized and summarized, as will be shown in the next item.

\section{Research results}

The frequency and position of words in writing is called Zipf's Law, homage to the Harvard University linguistics professor George Kingsley Zipf (1902-1950) (Jiang \& Jia, 2011). Jiang and Jia used this in order to question the arbitrarily or subjectively assigned geographic limits of counties in the United States. It is not within this study to engineer a statistic equation or devise linguistic and demographic datasets about this phenomenon. However, some thoughts arise by observing the map made through Vosviewer, a free tool available on the web. This software allows the creation of 
bibliometric networks and word networks in order to have a clear view of the relation between them.

The search carried out within the titles, keywords and abstracts of the 519 selected publications produced a network of data grouped into four clusters. An amount of 13,371 total items resulted into 318 significant terms. From these terms, a relevance score was calculated and used to select 191 terms ( $60 \%$ of the most relevant terms). A graphic representation of network terms was made by the software and is presented in Figure 2. The icon size is directly proportional to the occurrence ratio of a term in individual articles, disregarding the frequency of the term in a single article.

The clusters are differentiated by distinct colors for classification purposes only, devoid of other meanings. The red cluster has 81 items and gathers terms related with the decision making process. The more common terms are: alternative, solution, cost, stakeholder, performance and objective. The linking nodes of the words in this group are close. The green cluster can be interpreted much in the same way. This 59 term cluster is related with resource use and exploration and has the following terms as the most frequently present: factor, soil, water, watershed and parameters. Both groups (red and green) are closely related, although there is some distance between their nodes.

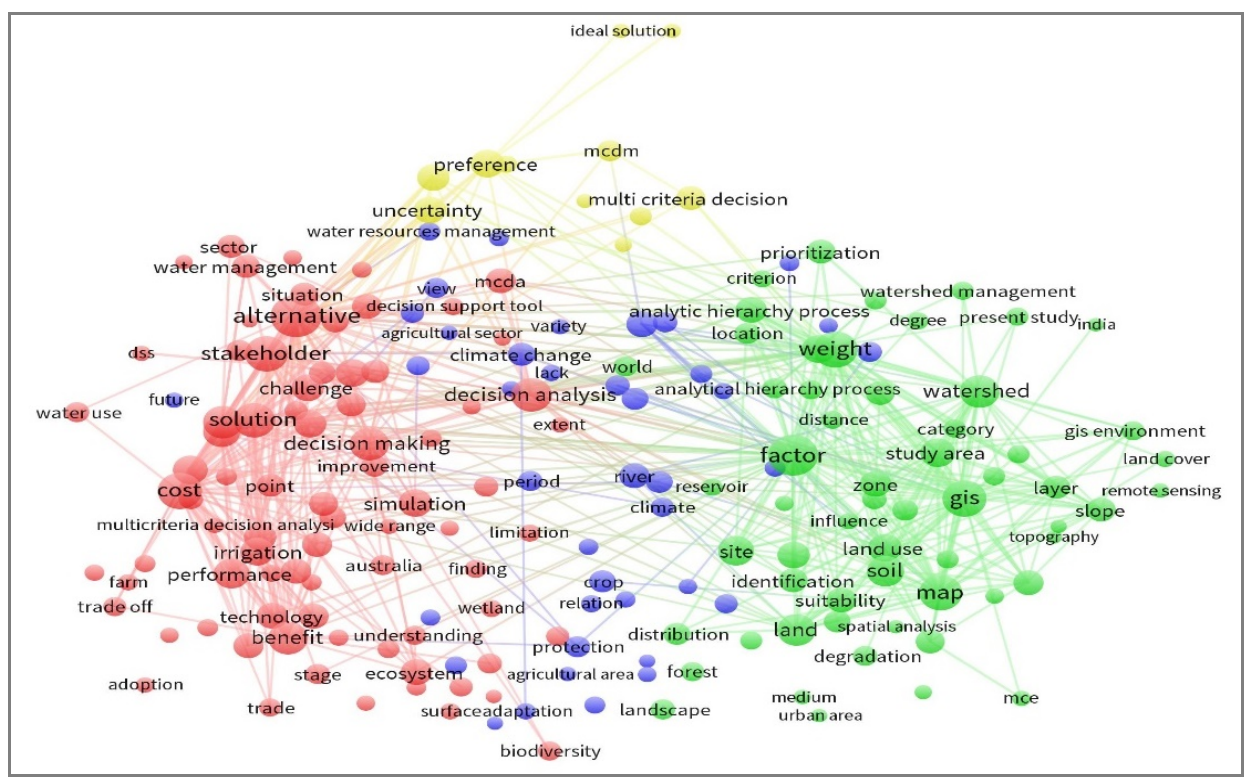

Figure 2. Association strength of the words most frequently used in the title, key words and abstracts of 519 publishings. Source: Authors.

Positioned between the former two, with 40 terms, the blue cluster highlights the following words: water, river, climate, pressure and protection. The last cluster, of yellow color, has 11 terms and is on the upper part of Figure 2. It relates to all other clusters, but fosters closer proximity more often with the green cluster. These elements can be labelled according to dimension, importance or frequency of terms through the usage of multicriteria methods. 


\subsection{Implementation of the search filters}

The bibliometric data gathered shows that the scientific articles containing multicriteria methods in water management had gradual growth throughout the analyzed time frame, totaling 499 publications between 2000 and July 2017. The annual average was of approximately 27 publications. Yet, the growth is substantially rises as of 2005 , in which the average increased to 35 articles per year. The standard deviation values were 17.3 and 14.1, respectively (Figure $3 \mathrm{~A}$ ).

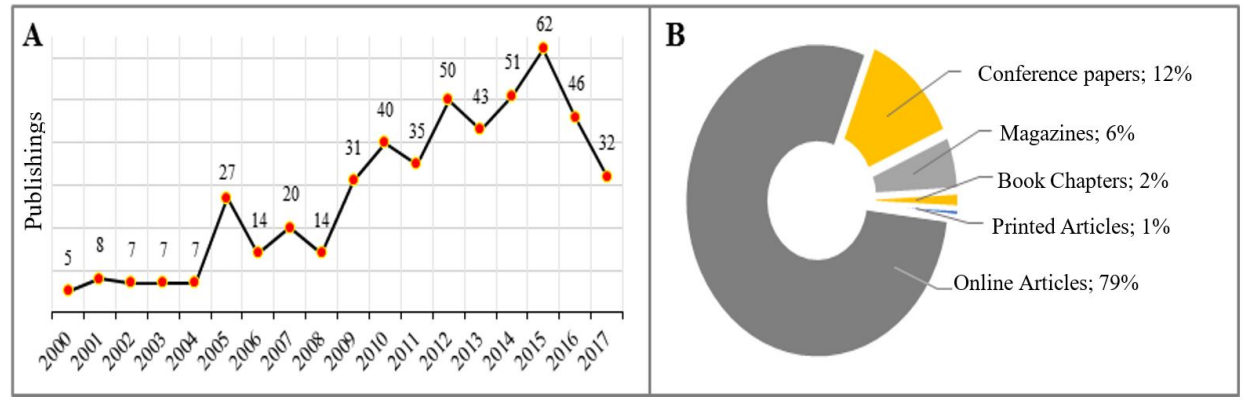

Figure 3. (A) Trends in the scientific production of Multicriteria Methods and water management in the 20002017 time span; (B) Dissemination means of the scientific production.

Note: The year of 2017 takes into account only the first seven months. Source: Authors based in Scopus (Elsevier, 2017) database.

Online articles (395 items) have shown to be more relevant among all publications (Figure 3B). They spread through 19 sub-areas of knowledge, with over $80 \%$ pertaining to: Environmental Science (46.3\%), Agricultural and Biological Science (12.9\%), Earth and Planetary Science (8.8\%), Engineering (8.6\%) and Social Sciences (6.0\%). Other areas were filtered out: Computer Science, Biochemistry, Business, Management and Accounting, Medicine, Chemical Engineering, Chemistry and Veterinary Medicine. After excluding the irrelevant publications with that filter, 339 articles were left.

The restrictive filter mentioned earlier acts by suppressing words that are not associated with the intended search results. This filtering has excluded the following words: Irrigation, due to an abundance of articles about irrigation systems optimization; Models Theoretical, for showing articles specifically about modeling and Geographic Information Systems, in which the publications are predominantly about georeferencing. This last filter reduced the document total to 219 items.

The next stage consisted of reading the titles of all publications in order to verify that they were all, in fact, aligned with the themes of water resources management in agriculture through multicriteria tools. This step is essentially of qualitative nature, and resulted in the selection of 80 potential articles. After reading their abstracts, results and closing remarks, 30 articles were chosen to take part in the framework of this bibliometric study, which will be examined shortly.

\subsection{Results analysis and discussion}

Based on the selected publications, this section will cover the following parameters: journal and article relevance, publication time frame and origin and, lastly, content analysis. 
Journal relevance to the area of knowledge of this study is measured through productivity, impact factor and number of citations that the journal amounts. The journals linked to the selected articles are distinguished, as will be shown in Figure 4.

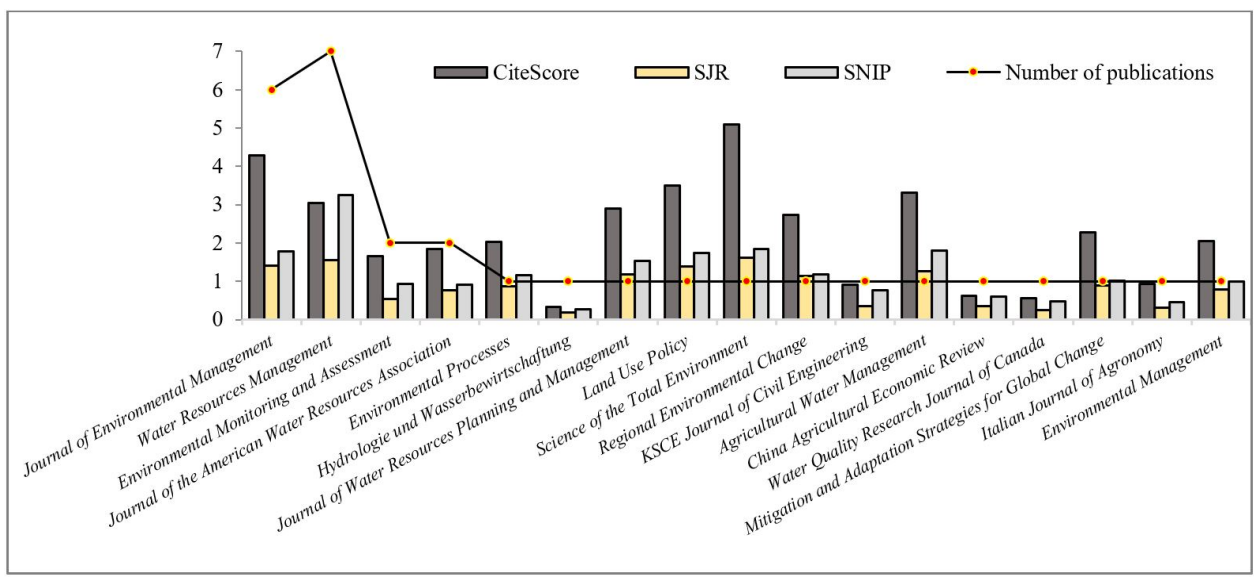

Figure 4. Article and quality distribution by journal for the 30 chosen articles. Source: Authors based in Scopus (Elsevier, 2017) database.

Over $40 \%$ of the selected articles were published by both the Journal of Environmental Management and Water Resources Management. The first also ranks first in number of citations received, amassing a total of 25,167 citations in 2016 alone (Figure 5).

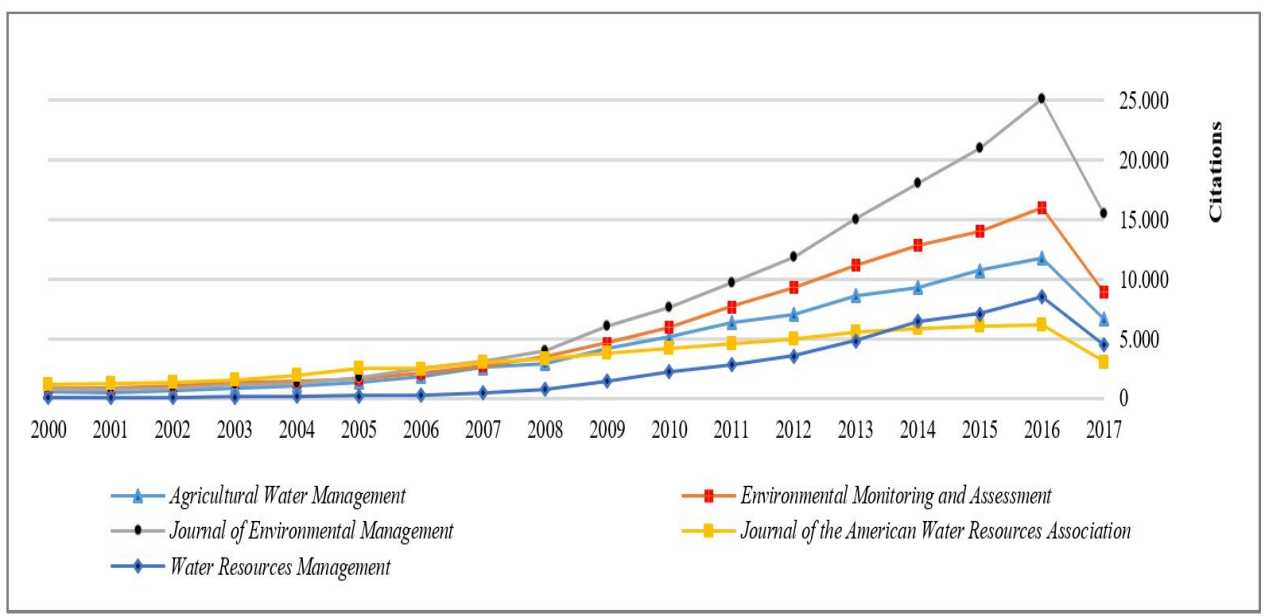

Figure 5. Citation frequency of the most referenced journals. Source: Authors based in Scopus (Elsevier, 2017) database.

The most cited articles are shown in Figure 6, representing $77.5 \%$ of the total citations within the 30 articles. Hermans et al. (2007) leads in this Figure, with 63 citations. It discusses the collaborative planning in river management through a multicriteria approach on a catchment basin in the northeastern United States. 


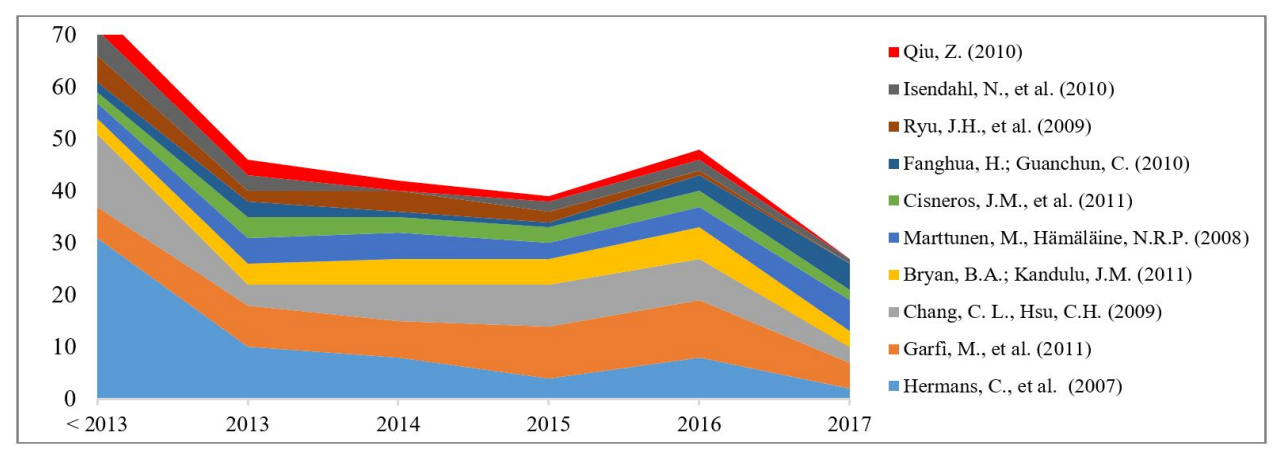

Figure 6. Citation frequency of the most referenced articles. Source: Authors based in Scopus (Elsevier, 2017) database.

The publications are concentrated over the last ten years, published mostly in the United States (Figure 7). The main affiliations of the published articles are: Feng Chia University (Taiwan), University of Tehran (Iran) and Universidad Politécnica de Madrid (Spain).

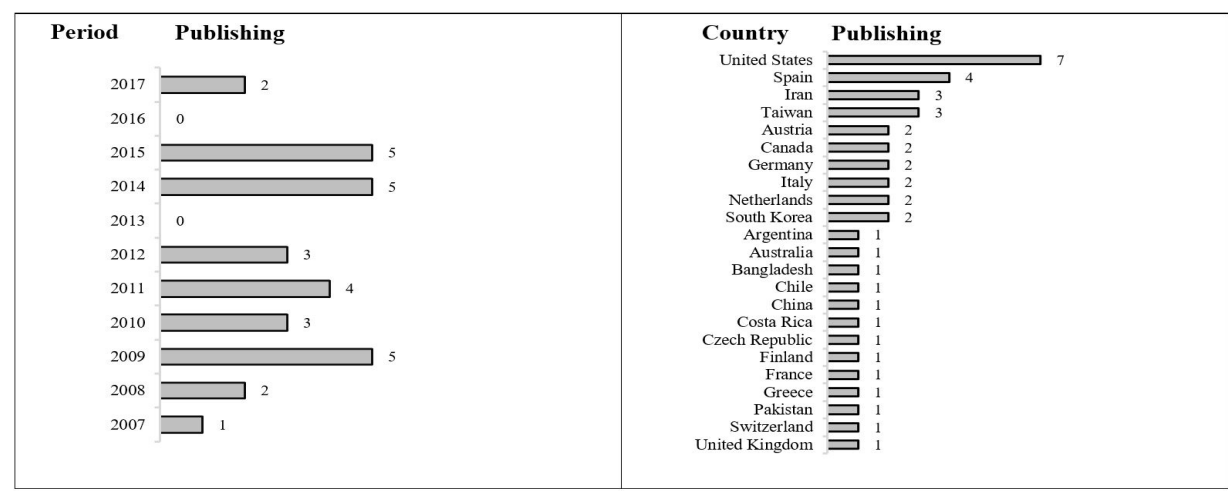

Figure 7. Time span and place of publication. Source: Authors based in Scopus (Elsevier, 2017) database.

The sampling of the selected articles (shown in Chart 2) was established considering one central criterion: the existing correspondence between the research problem in the articles and the present investigation object. Moreover, the proceedings used by the authors to solve their presented problems and the main results obtained with their studies were weighted. Afterwards, the aggregative, compensatory and participative characteristics presented in the initial assumptions and methods of the studies were categorized.

Chart 2. Analysis of the selected articles about water resources and their main assumptions regarding the use of Multicriteria Methods.

\begin{tabular}{|c|l|c|}
\hline Authors/Years & \multicolumn{1}{|c|}{ Article's Title } & Assumptions \\
\hline $\begin{array}{c}\text { Hermans et al. } \\
(2007)\end{array}$ & $\begin{array}{l}\text { Collaborative environmental planning in river } \\
\text { management: An application of multicriteria } \\
\text { decision analysis in the White River Watershed in } \\
\text { Vermont }\end{array}$ & $\begin{array}{c}\text { Aggregative } \\
\text { Non } \\
\text { compensatory } \\
\text { Participative }\end{array}$ \\
\hline
\end{tabular}


Chart 2. Continued...

\begin{tabular}{|c|c|c|}
\hline Authors/Years & Article's Title & Assumptions \\
\hline Garfi et al. (2011) & $\begin{array}{l}\text { Multi-criteria analysis for improving strategic } \\
\text { environmental assessment of water programmes. } \\
\text { A case study in semi-arid region of Brazil }\end{array}$ & $\begin{array}{c}\text { Aggregative } \\
\text { Compensatory } \\
\text { Non participative }\end{array}$ \\
\hline $\begin{array}{l}\text { Chang \& Hsu } \\
\quad(2009)\end{array}$ & $\begin{array}{l}\text { Multi-criteria analysis via the VIKOR method for } \\
\text { prioritizing land-use restraint strategies in the } \\
\text { Tseng-Wen reservoir watershed }\end{array}$ & $\begin{array}{c}\text { Aggregative } \\
\text { Compensatory } \\
\text { Non participative }\end{array}$ \\
\hline $\begin{array}{l}\text { Bryan \& Kandulu } \\
\qquad(2011)\end{array}$ & $\begin{array}{l}\text { Designing a Policy Mix and Sequence for } \\
\text { Mitigating Agricultural Non-Point Source Pollution } \\
\text { in a Water Supply Catchment }\end{array}$ & $\begin{array}{l}\text { Aggregative } \\
\text { Compensatory } \\
\text { Participative }\end{array}$ \\
\hline $\begin{array}{c}\text { Marttunen \& } \\
\text { Hämäläinen (2008) }\end{array}$ & $\begin{array}{l}\text { The decision analysis interview approach in the } \\
\text { collaborative management of a large regulated } \\
\text { water course }\end{array}$ & $\begin{array}{l}\text { Aggregative } \\
\text { Compensatory } \\
\text { Participative }\end{array}$ \\
\hline $\begin{array}{l}\text { Cisneros et al. } \\
\quad(2011)\end{array}$ & $\begin{array}{l}\text { Assessing multi-criteria approaches with } \\
\text { environmental, economic and social attributes, } \\
\text { weights and procedures: A case study in the } \\
\text { Pampas, Argentina }\end{array}$ & $\begin{array}{l}\text { Aggregative } \\
\text { Compensatory } \\
\text { Non participative }\end{array}$ \\
\hline $\begin{array}{c}\text { Fanghua \& } \\
\text { Guanchun (2010) }\end{array}$ & $\begin{array}{l}\text { A fuzzy multi-criteria group decision-making } \\
\text { model based on weighted Borda scoring method } \\
\text { for watershed ecological risk management: A } \\
\text { case study of Three Gorges Reservoir area of } \\
\text { China }\end{array}$ & $\begin{array}{l}\text { Aggregative } \\
\text { Compensatory } \\
\text { Participative }\end{array}$ \\
\hline Ryu et al. (2009) & $\begin{array}{l}\text { Sustainable water resources management in a } \\
\text { conflict resolution framework }\end{array}$ & $\begin{array}{l}\text { Aggregative } \\
\text { Compensatory } \\
\text { Participative }\end{array}$ \\
\hline $\begin{array}{l}\text { Isendahl et al. } \\
\qquad(2010)\end{array}$ & $\begin{array}{l}\text { Making framing of uncertainty in water } \\
\text { management practice explicit by using a } \\
\text { participant-structured approach }\end{array}$ & $\begin{array}{l}\text { Non aggregative } \\
\text { Non } \\
\text { compensatory } \\
\text { Participative }\end{array}$ \\
\hline Qiu (2010) & $\begin{array}{l}\text { Prioritizing agricultural lands for conservation } \\
\text { buffer placement using multiple criteria }\end{array}$ & $\begin{array}{l}\text { Aggregative } \\
\text { Compensatory } \\
\text { Non participative }\end{array}$ \\
\hline $\begin{array}{l}\text { Chang \& Chao } \\
\qquad(2012)\end{array}$ & $\begin{array}{l}\text { Using the analytical hierarchy process to assess } \\
\text { the environmental vulnerabilities of basins in } \\
\text { Taiwan }\end{array}$ & $\begin{array}{l}\text { Aggregative } \\
\text { Compensatory } \\
\text { Non participative }\end{array}$ \\
\hline Ravier et al. (2015) & $\begin{array}{l}\text { Multi-criteria and multi-stakeholder assessment } \\
\text { of cropping systems for a result-oriented water } \\
\text { quality preservation action programme }\end{array}$ & $\begin{array}{l}\text { Aggregative } \\
\text { Compensatory } \\
\text { Participative }\end{array}$ \\
\hline $\begin{array}{l}\text { Stefanopoulos et al. } \\
(2014)\end{array}$ & $\begin{array}{l}\text { Application of the Multi-Attribute Value Theory for } \\
\text { engaging stakeholders in groundwater protection } \\
\text { in the Vosvozis catchment in Greece }\end{array}$ & $\begin{array}{l}\text { Aggregative } \\
\text { Compensatory } \\
\text { Participative }\end{array}$ \\
\hline $\begin{array}{l}\text { Giupponi et al. } \\
\quad(2008)\end{array}$ & $\begin{array}{l}\text { Evaluation of Agri-environmental measures in the } \\
\text { Venice lagoon watershed. Expert knowledge } \\
\text { elicitation and multi-criteria analysis }\end{array}$ & $\begin{array}{l}\text { Non aggregative } \\
\text { Non } \\
\text { compensatory } \\
\text { Non participative }\end{array}$ \\
\hline Biswas et al. (2012) & $\begin{array}{l}\text { Evaluating integrated watershed management } \\
\text { using multiple criteria analysis - A case study at } \\
\text { chittagong hill tracts in Bangladesh }\end{array}$ & $\begin{array}{l}\text { Aggregative } \\
\text { Compensatory } \\
\text { Participative }\end{array}$ \\
\hline $\begin{array}{l}\text { Westbury et al. } \\
\qquad(2011)\end{array}$ & $\begin{array}{l}\text { Assessing the environmental performance of } \\
\text { English arable and livestock holdings using data } \\
\text { from the Farm Accountancy Data Network (FADN) }\end{array}$ & $\begin{array}{c}\text { Aggregative } \\
\text { Compensatory } \\
\text { Non participative }\end{array}$ \\
\hline Fedra (2015) & $\begin{array}{l}\text { River Basin Management: What do we Really } \\
\text { Want? }\end{array}$ & $\begin{array}{l}\text { Aggregative } \\
\text { Compensatory } \\
\text { Non participative }\end{array}$ \\
\hline Choi et al. (2012) & $\begin{array}{l}\text { Decision of the water shortage mitigation policy } \\
\text { using Multi-Criteria Decision Analysis }\end{array}$ & $\begin{array}{l}\text { Aggregative } \\
\text { Compensatory } \\
\text { Non participative }\end{array}$ \\
\hline
\end{tabular}


Chart 2. Continued...

\begin{tabular}{|c|c|c|}
\hline Authors/Years & Article's Title & Assumptions \\
\hline $\begin{array}{c}\text { Chitsaz \& } \\
\text { Azarnivand (2017) }\end{array}$ & $\begin{array}{l}\text { Water Scarcity Management in Arid Regions } \\
\text { Based on an Extended Multiple Criteria } \\
\text { Technique }\end{array}$ & $\begin{array}{l}\text { Aggregative } \\
\text { Compensatory } \\
\text { Participative }\end{array}$ \\
\hline $\begin{array}{c}\text { García de } \\
\text { Jalón et al. (2014) }\end{array}$ & $\begin{array}{l}\text { Building resilience to water scarcity in southern } \\
\text { Spain: A case study of rice farming in Doñana } \\
\text { protected wetlands }\end{array}$ & $\begin{array}{l}\text { Aggregative } \\
\text { Compensatory } \\
\text { Participative }\end{array}$ \\
\hline $\begin{array}{l}\text { Benegas et al. } \\
\qquad(2009)\end{array}$ & $\begin{array}{l}\text { A methodological proposal for the evaluation of } \\
\text { farmer's adaptation to climate variability, mainly } \\
\text { due to drought in watersheds in Central America }\end{array}$ & $\begin{array}{l}\text { Aggregative } \\
\text { Compensatory } \\
\text { Participative }\end{array}$ \\
\hline $\begin{array}{l}\text { Abed-Elmdoust \&, } \\
\text { Kerachian (2014) }\end{array}$ & $\begin{array}{l}\text { Evaluating the Relative Power of Water Users in } \\
\text { Inter-Basin Water Transfer Systems }\end{array}$ & $\begin{array}{l}\text { Aggregative } \\
\text { Compensatory } \\
\text { Non participative }\end{array}$ \\
\hline $\begin{array}{l}\text { Ahmadi et al. } \\
\qquad(2015)\end{array}$ & $\begin{array}{l}\text { Application of multicriteria decision analysis with } \\
\text { a priori knowledge to identify optimal nonpoint } \\
\text { source pollution control plans }\end{array}$ & $\begin{array}{c}\text { Aggregative } \\
\text { Compensatory } \\
\text { Non participative }\end{array}$ \\
\hline Atisa et al. (2014) & $\begin{array}{l}\text { Economic Assessment of Best Management } \\
\text { Practices in the Mara River Basin: Toward } \\
\text { Implementing Payment for Watershed Services }\end{array}$ & $\begin{array}{c}\text { Aggregative } \\
\text { Compensatory } \\
\text { Non participative }\end{array}$ \\
\hline $\begin{array}{l}\text { Booty \& Benoy } \\
\text { (2009) }\end{array}$ & $\begin{array}{l}\text { Multicriteria review of nonpoint source water } \\
\text { quality models for nutrients, sediments, and } \\
\text { pathogens }\end{array}$ & $\begin{array}{c}\text { Aggregative } \\
\text { Compensatory } \\
\text { Non participative }\end{array}$ \\
\hline $\begin{array}{l}\text { Ocampo- } \\
\text { Melgar et al. (2017) }\end{array}$ & $\begin{array}{l}\text { Potential of an outranking multi-criteria approach } \\
\text { to support the participatory assessment of land } \\
\text { management actions }\end{array}$ & $\begin{array}{l}\text { Aggregative } \\
\text { Non } \\
\text { compensatory } \\
\text { Participative }\end{array}$ \\
\hline Haider et al. (2015) & $\begin{array}{l}\text { Sustainability Evaluation of Surface Water } \\
\text { Quality Management Options in Developing } \\
\text { Countries: Multicriteria Analysis Using Fuzzy } \\
\text { UTASTAR Method }\end{array}$ & $\begin{array}{l}\text { Aggregative } \\
\text { Compensatory } \\
\text { Non participative }\end{array}$ \\
\hline Chang et al. (2014) & $\begin{array}{l}\text { Single criterion and multiple criteria analysis: } \\
\text { A comparison of water quality monitoring designs } \\
\text { for a river system }\end{array}$ & $\begin{array}{l}\text { Aggregative } \\
\text { Compensatory } \\
\text { Non participative }\end{array}$ \\
\hline $\begin{array}{l}\text { Grundmann \& } \\
\text { Schütze (2015) }\end{array}$ & $\begin{array}{l}\text { Technological challenges and solutions for an } \\
\text { optimal management of coupled groundwater- } \\
\text { agriculture hydrosystems in arid and semiarid } \\
\text { coastal regions }\end{array}$ & $\begin{array}{l}\text { Aggregative } \\
\text { Compensatory } \\
\text { Non participative }\end{array}$ \\
\hline $\begin{array}{l}\text { Mansoori et al. } \\
\qquad(2009)\end{array}$ & $\begin{array}{l}\text { Introducing a lexicographic goal programming for } \\
\text { environmental conservation program in farm } \\
\text { activities: A case study in Iran }\end{array}$ & $\begin{array}{l}\text { Aggregative } \\
\text { Non } \\
\text { compensatory } \\
\text { Non participative }\end{array}$ \\
\hline
\end{tabular}

Source: Authors; based in Scopus (Elsevier, 2017) database. Note: The articles are ranked in descending order based in the citation frequency.

As a whole, the most addressed research problems shown in Chart 2 were related to peculiarities of the decision making process within water resources management, like water distribution models, pollution reduction and prevention, economic and monetary optimization as well as other benefits from water related to the population's general wellbeing.

The articles evaluated scenarios considering some of the inherent aspects of the decision maker or the decision making group, such as values, objectives, prejudices, culture or intuition. In all of the chosen articles for this study, there is a certain prioritization of criteria in the study of potentialities (availability and quality) and the 
vulnerabilities in relation to demand and water usage (be it temporal, spatial, collective or individual).

It was observed that, in 28 articles, some form of aggregation or synthesis was used to consider the contribution of each of the criteria. This strategy was present in all but two works, in which the focus was not categorization or ranking but, as stated by Roy (2013), the description of the context and/or understanding of the alternatives.

Additionally, in those 28 articles, each evaluation criteria applied a mathematical function to measure the performance of the potential actions of an aspect. An example is the Analytic Hierarchy Process (AHP), introduced by Thomas Saaty in the 1980s (Saaty, 1980). This aggregation process helps in identifying the best alternative within a predefined set of criteria was used in 11 articles.

Overall, not only the AHP related, but all of the selected publications judged several parameters and quantity indicators (for different uses) and quality (for different pollutants) of the water. These indicators are often related to the balance between the supply and demand of water in a catchment basin and are integrated to the local context in addition to the social and economic roles that water plays in the evaluated circumstances.

In a way, aggregation seems to be linked to the compensatory nature among criteria. This situation is present in 25 works. That is, worsening one criterion can be compensated by improving another. These assumptions greatly depend on the type of problem at hand, the stakeholders and the criteria involved in the model. For instance, it is possible that the environmental damage due to the use of water sources in catchment basins can be compensated by income or job improvements derived by that same use (see Garfi et al., 2011). In the work of Cisneros et al. (2011), the compensatory mechanism itself can help in the process of negotiation for choosing between intensive cropping systems, by rotating soy and corn, versus conservation systems of pastures and forests. Since policy makers are used to dealing with these kinds of trade-offs, it may be considered that the compensatory assumption is convergent with this behavior.

The last aspect left to discuss is the participatory nature of the modeling process. In 17 articles, both establishing the criteria and setting up the model were done by the analyst or by experts. This case is seen in the work of Choi et al. (2012) about the assessment of long term policies in the Nakdong river catchment, in South Korea. Generally, the risk in this type of model is that the rationality of the analyst or the experts is not necessarily the same rationality of the stakeholders.

Conversely, some form of involvement of stakeholders was found in 13 articles. In these works, like the article of Biswas et al. (2012), they rely on several experts, professionals and lobby groups to create a hierarchy of criteria both qualitative and quantitative. Furthermore, they used psychometric tools to perform diagnosis. Information related to the perception of interested parties such as: farmers, local and regional authorities, environmental regulatory agencies, experts, among others were taken into account through oriented surveys. They used AHP to assess different strategies of use and management of the Chittagong Hill Tracts catchment basin in Bangladesh. In situations where the study involved a large number of people, like in case reported by Ocampo-Melgar et al. (2017), non-compensatory procedures were employed transparently enough to ensure stakeholder commitment.

Still regarding the engagement of multiple stakeholders, Ravier et al. (2015) have relied on individual surveys that helped them in building a comprehensive multicriteria model and, yet, suited to the local issues. They showed that public measures of 
financial incentives were used to foster farmers in adopting practices of low environmental impact, such as the use reduction of nitrogen fertilizers and pesticides, but they were not effective enough to be reflected in better water quality. However, this research also shows that a combination of aspects (economic, social, geographic, among others) established through incentives and fines, with objectives jointly agreed among stakeholders (farmers, developing agents, public managers) can be an effective alternative to overcome the externalities that are being carried over to the water resources.

The main objectives noted in the articles of the present research are trying to plan a set of policies, measures and cost effective technologies near the standard solution (as a reference), to guide decisions toward to a set of attainable values (Fedra, 2015). In a certain sense, it means to consider that the problem happens to be structured from a simulation in a standard context, often considered as a utopian situation. These simulations are used to steer decisions and actions toward real and intended objectives.

According to Bryan \& Kandulu (2011), the State and civil society tend toward traditional and individualized tools when facing problems of water quality management in agriculture. This results in inefficient and improper forms of governance of water resources which, in turn, can worsen the problems of water quality, mainly: (a) when there is a lack of understanding among farmers about the effects of land use on the water resources; (b) in cases of labor shortage in agriculture; (c) when consultants and extensionists are limited in competence and availability; (d) in the absence or lack of knowledge of regulatory mechanisms; (e) when the agriculture and management in private properties is not compatible with the collective process of decision making in the management of water resources.

Therefore, it seems that in the literature reviewed the actions put in place at the macro level, when: (a) they were established and structured together with farmers; and (b) in a result-oriented fashion (there are rewards associated with positive consequences), are perceived with optimism to align agricultural production and the conservation of natural resources. These actions are established and implemented with stakeholder engagement and consider a wide range of management strategies. Hence, they can stimulate the stakeholders' commitment and foster an appropriate management to the special characteristics of local socioeconomics and environmental context. This is one way to promote short, medium and long term effects over water quality.

Finally, although in some cases an agreement among stakeholders was not reached and, consequently, objectives were left to reconcile, Ravier et al. (2015) stresses that discussing and structuring problems through multicriteria tools at least provided a favorable arena for debate while acknowledging its multiple points of view. As a result, even with remaining competing objectives, with non-unanimous decisions, those authors are optimistic in regards to a possible harmonization in the long term.

\section{Final comments}

The impact of agricultural land use and improper management practices in water abstraction areas can affect parts of the population beyond those directly involved with the agricultural sector. Therefore, it is worth noting that not only the controllable elements and conditions inherent to the local context, but also those that the farmers have little to no control over must be taken into account in the decision processes, as 
are the cases of legislation, governmental incentives, and market, among others that are indirectly connected to the local environment.

The reviewed articles show that the use of Multicriteria Methods in studies about water resources management are mainly aggregative and compensatory. However, there is a clear distinction in terms of stakeholder participation. In some of them, they play a major role, while in others the analyst and the experts are the leading figures.

The participative Multicriteria Methods have been capable of acknowledging and integrating aspects such as tradition, intuition and power relationship, all of which directly affect decision making, the definition of objectives and conflict management. Although these themes are considered a subjective matter, they have always been endorsed by the scientific community. When considering aspects of objective nature (related to actions) as well as those of subjective nature (related to the value of the actors), the decision process results in a better water management, which is increasingly important to understand the factors limiting the boundaries of human development.

Thus, in a process of construction and evaluation of alternatives, awareness is necessary to guarantee the engagement of all stakeholders (public users of water, the ones responsible for the water supply and public sewage, the power generation sector, rural sector, industrial sector, shipping and mining, tourism and leisure, among others), in order to avoid wrongly supporting decisions based in outlier values that benefit only some of the involved parties.

The performance of the agricultural policies of the developed countries in which most of the studies took place should be highlighted. Specifically, those of the European Union have been providing a basic level of security to the farmers through an income ensuring program. This is a rather different situation than what is observed in developing countries, like Brazil, and may be an important constraint to the results.

The experiences observed in this bibliographic survey about the use of Multicriteria Methods in the management of water resources do not seem to be definitive or conclusive to design alternatives in the light of the family farm systems. The study of Ravier et al. (2015) was the one closest to this point of view. However, they did not try to establish the differences and similarities among production systems while looking for parallels with farmer and property characteristics, as well as the environmental quality-related strategies used in the production systems. This gap may be explored in future studies.

Moreover, this research has made it evident that the Multicriteria Methods, despite its limitations, are useful in the decision making processes where uncertainties are present, like in the case of natural resources. One of its main strengths is the potential to provide alternatives in circumstances where only partial data is available or, even, in cases in which data is difficult to quantify.

Lastly, the main limitation of this bibliometric research is related to the sensibility of the criteria and filters used to generate the sample. Depending on the search query operators used, it is possible that the process might hide some relevant publications. But, conversely, searching through the references of the selected articles may mitigate this side effect by unveiling studies not included in the sample, but that can somehow contribute to the comprehension of the subject covered.

\section{Acknowledgments}

The authors thank the reviewers who, in a definitive way, contributed to a better version of this work. In addition, a special thanks to Vitória Motta Gomes, undergraduate student of Library Science from Federal University of Rio Grande do Sul, who kindly helped with the English version of this work. 


\section{References}

Abed-Elmdoust, A., \& Kerachian, R. (2014). Evaluating the relative power of water users in inter-basin water transfer systems. Water Resources Management, 28(2), 495-509. http://dx.doi.org/10.1007/s11269-013-0495-9.

Agência Nacional de Águas - ANA. (2012). Panorama da qualidade das águas superficiais do Brasil 2012. Brasília: ANA. Retrieved in 2017, October 18, from

http://arquivos.ana.gov.br/imprensa/publicacoes/Panorama_Qualidade_Aguas_Superficiais _BR_2012.pdf

Ahmadi, M., Arabi, M., Fontane, D., \& Engel, B. (2015). Application of multicriteria decision analysis with a priori knowledge to identify optimal nonpoint source pollution control plans. Journal of Water Resources Planning and Management, 141(2), 4014054. http://dx.doi.org/10.1061/(ASCE)WR.1943-5452.0000455.

Atisa, G., Bhat, M. G., \& Mcclain, M. E. (2014). Economic assessment of best management practices in the Mara river basin: toward implementing payment for watershed services. Water Resources Management, 28(6), 1751-1766. http://dx.doi.org/10.1007/s11269-0140585-3.

Bana e Costa, C. A., \& Pirlot, M. (1997). Thoughts on the future of the multicriteria field: basic convictions and outlines for a general methodology. In J. Clímaco (Ed.), Multicriteria analysis (pp. 562-568). Berlin: Springer. https://doi.org/10.1007/978-3-642-60667-0_53.

Benegas, L., Jiménez, F., Locatelli, B., Faustino, J., \& Campos, M. (2009). A methodological proposal for the evaluation of farmer's adaptation to climate variability, mainly due to drought in watersheds in Central America. Mitigation and Adaptation Strategies for Global Change, 14(2), 169-183. http://dx.doi.org/10.1007/s11027-008-9158-1.

Biswas, S., Vacik, H., Swanson, M., \& Haque, S. (2012). Evaluating integrated watershed management using multiple criteria analysis - a case study at chittagong hill tracts in Bangladesh. Environmental Monitoring and Assessment, 184(5), 2741-2761. http://dx.doi.org/10.1007/s10661-011-2148-x. PMid:21674224.

Booty, W., \& Benoy, G. (2009). Multicriteria review of nonpoint source water quality models for nutrients, sediments, and pathogens. Water Quality Research Journal of Canada, 44(4), 365-377. http://dx.doi.org/10.2166/wqrj.2009.037.

Brasil. (1988,5 de outubro). Constituição da República Federativa do Brasil. Brasília, DF: Diário Oficial da República Federativa do Brasil.

Bryan, B. A., \& Kandulu, J. M. (2011). Designing a policy mix and sequence for mitigating agricultural non-point source pollution in a water supply catchment. Water Resources Management, 25(3), 875-892. http://dx.doi.org/10.1007/s11269-010-9731-8.

Chang, C. L., \& Chao, Y. C. (2012). Using the analytical hierarchy process to assess the environmental vulnerabilities of basins in Taiwan. Environmental Monitoring and Assessment, 184(5), 2939-2945. http://dx.doi.org/10.1007/s10661-011-2162-z. PMid:21713488.

Chang, C. L., \& Hsu, C. H. (2009). Multi-criteria analysis via the VIKOR method for prioritizing land-use restraint strategies in the Tseng-Wen reservoir watershed. Journal of Environmental Management, 90(11), 3226-3230. http://dx.doi.org/10.1016/j.jenvman.2009.04.020. PMid:19482411.

Chang, C. L., Lin, Y. T., \& Chiueh, P. T. (2014). Single criterion and multiple criteria analysis: A comparison of water quality monitoring designs for a river system. Water Resources Management, 28(3), 645-655. http://dx.doi.org/10.1007/s11269-013-0505-y.

Chitsaz, N., \& Azarnivand, A. (2017). Water scarcity management in arid regions based on an extended multiple criteria technique. Water Resources Management, 31(1), 233-250. http://dx.doi.org/10.1007/s11269-016-1521-5. 
Choi, S. J., Kim, J. H., \& Lee, D.-R. (2012). Decision of the water shortage mitigation policy using Multi-Criteria Decision Analysis. KSCE Journal of Civil Engineering, 16(2), 247-253. http://dx.doi.org/10.1007/s12205-012-0008-z.

Cisneros, J. M., Grau, J. B., Antón, J. M., De Prada, J. D., Cantero, A., \& Degioanni, A. J. (2011). Assessing multi-criteria approaches with environmental, economic and social attributes, weights and procedures: A case study in the Pampas, Argentina. Agricultural Water Management, 98(10), 1545-1556. http://dx.doi.org/10.1016/j.agwat.2011.05.009.

Ehrgott, M., Figueira, J., \& Greco, S. (2010). Trends in multiple criteria decision analysis. New York: Springer. http://dx.doi.org/10.1007/978-1-4419-5904-1.

Elsevier. (2017). SCOPUS: guia de referência rápida. Retrieved in 2017, October 18, from https://www.elsevier.com/solutions/scopus

Ensslin, L., Montibeller, G., No., \& Noronha, S. M. (2001). Apoio à decisão: metodologia para estruturação de problemas e avaliação multicritério de alternativas (296p.). Florianópolis: Insular.

Fanghua, H., \& Guanchun, C. (2010). A fuzzy multi-criteria group decision-making model based on weighted Borda scoring method for watershed ecological risk management: a case study of Three Gorges Reservoir area of China. Water Resources Management, 24(10), 2139-2165. http://dx.doi.org/10.1007/s11269-009-9544-9.

Fedra, K. (2015). River basin management: what do we really want? environmental software and services $\mathrm{GmbH}$, Möedling, Austria. Environmental Processes, 2(3), 511-525. http://dx.doi.org/10.1007/s40710-015-0084-4.

Funtowicz, S., \& Ravetz, J. (1997). Ciência Pós-Normal e comunidades ampliadas dos pares face aos desafios ambientais. História. Ciência \& Saúde (Porto Alegre), 4, 219-230.

García de Jalón, S., Iglesias, A., Cunningham, R., \& Pérez Díaz, J. I. (2014). Building resilience to water scarcity in southern Spain: a case study of rice farming in Doñana protected wetlands. Regional Environmental Change, 14(3), 1229-1242. http://dx.doi.org/10.1007/s10113-013-0569-5.

Garfi, M., Ferrer-Martí, L., Bonoli, A., \& Tondelli, S. (2011). Multi-criteria analysis for improving strategic environmental assessment of water programmes. A case study in semi-arid region of Brazil. Journal of Environmental Management, 92(3), 665-675. http://dx.doi.org/10.1016/j.jenvman.2010.10.007. PMid:21035244.

Giupponi, C., Fassio, A., \& Sgobbi, A. (2008). Evaluation of Agri-environmental measures in the Venice lagoon watershed. Expert knowledge elicitation and multi-criteria analysis. Italian Journal of Agronomy, 3(3), 147-165. http://dx.doi.org/10.4081/ija.2008.147.

Greco, S., Figueira, J., \& Ehrgott, M. (2016). Multiple criteria decision analysis (1347 p.). New York: Springer. http://dx.doi.org/10.1007/978-1-4939-3094-4.

Grundmann, J., \& Schütze, N. (2015). Technological challenges and solutions for an optimal management of coupled groundwater-agriculture hydrosystems in arid and semiarid coastal regions. Hydrologie und Wasserbewirtschaftung, 59(5), 240-246.

Haider, H., Singh, P., Ali, W., Tesfamariam, S., \& Sadiq, R. (2015). Sustainability evaluation of surface water quality management options in developing countries: multicriteria analysis using fuzzy UTASTAR Method. Water Resources Management, 29(8), 2987-3013. http://dx.doi.org/10.1007/s11269-015-0982-2.

Hermans, C., Erickson, J., Noordewier, T., Sheldon, A., \& Kline M. (2007). Collaborative environmental planning in river management: an application of multicriteria decision analysis in the White River Watershed in Vermont. Journal of Environmental Management, 84(4), 534-546.

Isendahl, N., Dewulf, A., \& Pahl-Wostl, C. (2010). Making framing of uncertainty in water management practice explicit by using a participant-structured approach. Journal of Environmental Management, 91(4), 844-851. http://dx.doi.org/10.1016/j.jenvman.2009.10.016. PMid:19945210. 
Jiang, B., \& Jia, T. (2011). Zipf's law for all the natural cities in the United States: a geospatial perspective. International Journal of Geographical Information Science, 25(8), 1269-1281. http://dx.doi.org/10.1080/13658816.2010.510801.

Lemke, A. M., Lindenbaum, T. T., Perry, W. L., Herbert, M. E., Tear, T. H., \& Herkert, J. R. (2010). Effects of outreach on the awareness and adoption of conservation practices by farmers in two agricultural watersheds of the Mackinaw River, Illinois. Journal of Soil and Water Conservation, 65(5), 304-315. http://dx.doi.org/10.2489/jswc.65.5.304.

Lima, A. P., Basso, N., Neumann, P. S., Santos, A. C., \& Müller, A. G. (2005). Administração da unidade de produção familiar: modalidades de trabalho com agricultores (3. ed.). ljuí: Unijuí.

Lynne, D., Shonkwiler, J. S., \& Rola, L. R. (1988). Attitudes and farmer conservation behavior. Journal of Agricultural Economics, 70(1), 12-19. http://dx.doi.org/10.2307/1241971.

Mansoori, H., Reza Kohansal, M., \& Farid Khadem Ghousi, M. (2009). Introducing a lexicographic goal programming for environmental conservation program in farm activities: a case study in Iran. China Agricultural Economic Review, 1(4), 478-484. http://dx.doi.org/10.1108/17561370910989284.

Marttunen, M., \& Hämäläinen, R. P. (2008). The decision analysis interview approach in the collaborative management of a large regulated water course. Environmental Management, 42(6), 1026-1042. http://dx.doi.org/10.1007/s00267-008-9200-9. PMid:18830741.

Napier, T. L., Tucker, M., \& Mccarter, S. (2000). Adoption of conservation production systems in three Midwest watersheds. Journal of Soil and Water Conservation, 55(2), 123-134.

Ocampo-Melgar, A., Bautista, S., Edward de Steiguer, J., \& Orr, B. J. (2017). Potential of an outranking multi-criteria approach to support the participatory assessment of land management actions. Journal of Environmental Management, 195(Pt 1), 70-77. http://dx.doi.org/10.1016/j.jenvman.2016.11.041. PMid:27939775.

Pes, J. H. F. (2005). O Mercosul e as água: a harmonização via Mercosul, das normas de proteção às águas transfronteiriças do Brasil e Argentina. Santa Maria: Ed. da UFSM.

Pritchard, A. (1969). Statistical bibliography or bibliometrics? The Journal of Documentation, 25, 348-349.

Prokopy, K., Floress, D., Klotthor-weinkauf, A., \& Baumgart-Getz, A. (2008). Determinants of agricultural best management practice adoption: evidence from the literature. Journal of Soil and Water Conservation, 65(5), 300-311. http://dx.doi.org/10.2489/jswc.63.5.300.

Qiu, Z. (2010). Prioritizing agricultural lands for conservation buffer placement using multiple criteria. Journal of the American Water Resources Association, 46(5), 944-956. http://dx.doi.org/10.1111/j.1752-1688.2010.00466.x.

Ravier, C., Prost, L., Jeuffroy, M., Wezel, A., Paravano, L., \& Reau, R. (2015). Multi-criteria and multi-stakeholder assessment of cropping systems for a result-oriented water quality preservation action programme. Land Use Policy, 42, 131-140. http://dx.doi.org/10.1016/j.landusepol.2014.07.006.

Roy, B. (1993). Decision Science or Decision Aid Science? European Journal of Operational Research, 6(2), 184-203. http://dx.doi.org/10.1016/0377-2217(93)90312-B.

Roy, B. (2013). Multicriteria methodology for decision aiding (Vol. 12, 276 p.). USA: Springer Science \& Business Media.

Roy, B., \& Vanderpooten, D. (1996). The European school of MCDA: emergence, basic features and current works. Journal of Multi-Criteria Decision Analysis, 5(1), 22-38. http://dx.doi.org/10.1002/(SICI)1099-1360(199603)5:1<22::AID-MCDA93>3.0.CO;2-F.

Ryan, R., Erickson, R., \& Young, R. (2003). Farmers' motivations for adopting conservation practices along riparian zones in a mid-western agricultural watershed. Journal of Environmental Planning and Management, 46(1), 19-37. http://dx.doi.org/10.1080/713676702. 
Ryu, J. H., Palmer, R., Jeong, S., Lee, J., \& Kim, Y. (2009). Sustainable water resources management in a conflict resolution framework. Journal of the American Water Resources Association, 45(2), 485-499. http://dx.doi.org/10.1111/j.1752-1688.2009.00304.x.

Saaty, T. L. (1980). The analytic hierarchy process. New York: McGraw-Hill.

Stefanopoulos, K., Yang, H., Gemitzi, A., \& Tsagarakis, K. (2014). Application of the multiattribute value theory for engaging stakeholders in groundwater protection in the Vosvozis catchment in Greece. The Science of the Total Environment, 470-471, 26-33. http://dx.doi.org/10.1016/j.scitotenv.2013.09.008. PMid:24121661.

Tosakana, N. S. P., Van Tassell, L. W., Wulfhorst, J. D., Boll, J., Mahler, R., Brooks, E. S., \& Kane, S. (2010). Determinants of the adoption of conservation practices by farmers in the northwest wheat and range region. Journal of Soil and Water Conservation, 65(6), 404412. http://dx.doi.org/10.2489/jswc.65.6.404.

Treinta, F. T., Farias, J. R., Fo., Sant'Anna, A. P., \& Rabelo, L. M. (2014). Metodologia de pesquisa bibliográfica com a utilização de método multicritério de apoio à decisão. Prod., 24(3), 508-520. http://dx.doi.org/10.1590/S0103-65132013005000078.

Vanti, N. (2002). Da bibliometria à webometria: uma exploração conceitual dos mecanismos utilizados para medir o registro da informação e a difusão do conhecimento. Ciência da Informação, 31(2), 152-162. http://dx.doi.org/10.1590/S0100-19652002000200016.

Westbury, D. B., Park, J., Mauchline, A., Crane, R., \& Mortimer, S. (2011). Assessing the environmental performance of English arable and livestock holdings using data from the Farm Accountancy Data Network (FADN). Journal of Environmental Management, 92(3), 902-909. http://dx.doi.org/10.1016/j.jenvman.2010.10.051. PMid:21075506.

Xavier, J. H. V., Gomes, M. C., Sacco dos Anjos, F., Almeida, S. C. R., Oliveira, M. N., Scopel, E., Corbeels, M., \& Muller, A. G. (2012). Metodologia multicritério de apoio à decisão como ferramenta para avaliação de sistemas de cultivo de milho. Cadernos de Ciência \& Tecnologia, 29, 89-131.

Zopounidis, C., \& Doumpos, M. (Eds.), (2016). Multiple criteria decision making: applications in management and engineering (211 p.). New York: Springer. 